\title{
Innovation processes in Kazakhstan: development factors
}

\author{
Mansia Sadyrova ${ }^{1 *}\left(\mathbb{0}\right.$, Kuanish Yusupov ${ }^{2}$ and Bibigul Imanbekova ${ }^{3}$
}

\author{
${ }^{*}$ Correspondence: \\ sadyrova_mansia@rambler.ru \\ ${ }^{1}$ Department of Sociology \\ and Social Work, Al-Farabi \\ Kazakh National University, \\ Almaty, Kazakhstan \\ Full list of author information \\ is available at the end of the \\ article
}

\begin{abstract}
The paper analyzes and assesses the main issues and development factors of innovation processes in Kazakhstan. It is known that in modern conditions of dynamically developing competitive processes and scientific and technological progress, innovations serve as the basis of the national economy and a key factor in ensuring the competitiveness of enterprises. Moreover, today, the economy of the country can successfully compete in the market on the basis of the continuous improvement of goods and services produced as well as the development of new directions. It is also obvious that the development of new products, implementation of innovations and new measures are key performance indicators at both the macro and microeconomic levels. In this sense, an innovative way of socio-economic development of the country is becoming an urgent problem for Kazakhstan. An analysis of the situation shows that in the real sector of the economy, the possibilities of increasing production at the expense of extensive factors are largely exhausted. It is necessary to ensure the modernization of the economy through the introduction of modern technologies and the maximum use of the country's intellectual potential. The realization of the economic strategy determines the implementation of the main directions of social policy in line with the innovative development of Kazakh society as a whole.
\end{abstract}

Keywords: Innovation, Management, Government, Central Asia, Investment, Project

\section{Introduction}

Throughout the history of mankind, innovation has been the driving force and source of development. Innovation refers to the process of transforming knowledge and ideas into products or services that have consumer value. Today, the governments of the leading countries of the world, including Russia, have set a course to build a "knowledge economy "or" innovation economy", where knowledge and innovation play a leading role (Kudryavtseva, 2019). Nowadays, innovation is a prerequisite for the long-term sustainable operation and development of any enterprise. An innovation process (IP) is the process of commercializing new technologies or converting knowledge into innovation. To organize an effective individual entrepreneur in an enterprise, it is necessary to clearly understand its time specifics. The modern world economy (the new economy) has a number of features, such as globalization, dynamism, continuous and rapid variability, tougher competition, shorter life cycles of goods, ever-increasing speed of information

(c) The Author(s) 2021. Open Access This article is licensed under a Creative Commons Attribution 4.0 International License, which permits use, sharing, adaptation, distribution and reproduction in any medium or format, as long as you give appropriate credit to the original author(s) and the source, provide a link to the Creative Commons licence, and indicate if changes were made. The images or other third party material in this article are included in the article's Creative Commons licence, unless indicated otherwise in a credit line to the material. If material is not included in the article's Creative Commons licence and your intended use is not permitted by statutory regulation or exceeds the permitted use, you will need to obtain permission directly from the copyright holder. To view a copy of this licence, visit http:// creativecommons.org/licenses/by/4.0/. 
flows, increasing complexity of its constituent systems, the increased role of knowledge and intellectual capital (Bassellier et al., 2001).

Innovative development of the country is one of the strategic objectives of Kazakhstan. The innovative way of development provides achievement of economic growth, both by active implementation of innovations, and GDP growth at the expense of profit from innovative activity (Gareev, 2017). Today, in terms of economic relations in the Republic of Kazakhstan, innovation from the state point of view is the main strategic object of the country's development as a whole. According to some foreign researchers Kazakhstan is ahead of neighboring countries in this respect (Bhatt \& Grover, 2005). Therefore, it will be relevant to study the issue of state support for the development of innovation in the country. It should be mentioned that by the beginning of the twenty-first century, it became obvious that the level of development and dynamism of the innovation sphere that is science, new technologies, knowledge-intensive industries and companies such as forms the basis for sustainable economic growth, defines the boundary between rich and poor countries. The formation of national innovation systems as the main mechanism for self-development has become a major factor in the long-term growth of the global economy (Begentayev, 2018).

In the message of the President of the Republic of Kazakhstan, Nursultan Nazarbayev, "The New Decade-New Growth-New Opportunities of Kazakhstan" notes that in the new decade "Kazakhstan will be a successful industrial power". Achieving the most important milestones of the country's economic development should be provided by the State Program of Forced Industrial-Innovative Development and a detailed Map of the country's industrialization. According to these documents and state programs, the direction and structure of the economy are changing towards the development of nonprimary exports and manufacturing industries (Mukhamedzhanov, 2011).

Indeed, it is really significant. Often, using this or that term, we stop paying attention to its content. As a result, formalization takes place, leading to the incoherence and obscurity of the term.

This paper presents an original and reflexive study in how the factors of development of the innovation process in Kazakhstan are arranged. The purpose of this study is to contribute to the optimization of scientific research in the field of innovation in Kazakhstan.

\section{Literature review}

General trends of innovative development in the world and the role of technology in it are considered in the works Carlsson and Stankiewicz (1991). There is no doubt that Japan is an advanced country in the use of innovative projects in the field of economic management. British economist Freeman in his research (Freeman, 2015) showed what achievements Japan has achieved in the economy by applying technological policy at the turn of the $90 \mathrm{~s}$.

The American scientist Grant in his works (Grant, 1996) was one of the first in the world to promote that in the structure of business it is important to know and apply new methods of technology. He claims that the use of advanced technologies determines the company's competitiveness. American scientists studying innovation Klin, Rosenberg play a significant role in the study of innovative economic development in other 
countries. They don't pay attention to things that other experts think don't affect the overall trend. In their works (Kline \& Rosenberg, 2015), you can find reviews and analysis on the innovations of developing countries in Asia and Africa.

British expert on the innovative activities of the state Lundvall he showed in his work (Lundvall, 2016) how the system of innovation activity of the EU countries is organized. He cites vivid examples from the real life of Eastern European countries that their innovation system is still isolated from Western European countries.

Another Western scientist Rothwell in his research (Rothwell, 2015) claims and promotes the idea that many countries of the world are still on the way to the innovation process of the fifth generation. The role of innovative technologies in education has been discussed in Freeman's works (Freeman, 2015).

We can say that the study of the innovation process in the post-Soviet States does not have a specific scientific and theoretical approach. Including in Kazakhstan. Innovative projects are implemented at the state level, but not effectively. This is especially true in Central Asian countries. Research on the innovation process is more supported in Russia and Georgia. In the Central Asian States, scientists cannot analyze, because there are no prerequisites for this. In Kazakhstan, you can find a couple of scientific papers on this topic. Mechanisms of innovative development of the Russian economy are justified in the publications of Naumenko (2016). The openness of the Russian market to innovative technologies is analyzed in the works of Chesbro (2017). A similar course of research was conducted with other Russian experts such as Gogoleva (2017) and Bukhalova (2018). Recent achievements of innovative goals and objectives in the field of education are analyzed in the work of Efremova (2018). In Kazakhstan, several authors stand out on these issues. The leading one is Alimzhzhanov. His research evaluated the results of the introduction of innovative technologies in Kazakhstan in the early 2000s (Alimzhzhanov, 2011).

The research of Begentayev (2018) is a valuable work in comparison of statistical data in the field of innovation. He made a synthesis of data on the use of innovative technologies in Kazakhstan since the early 90s. The latest indicators of innovative projects in the sphere of services and goods were presented in Kazhymurat's research (2017).

Recently, Kazakh scientists have begun to pay more attention to the topic of innovative education. This topic is gaining more and more popularity and demand among researchers.

The rationale for writing this article is to obtain new experimental data on innovative projects that affect the development factor of Kazakhstan.

The purpose of the research is to show the mechanism of formation and development of innovative activity in Kazakhstan based on world experience.

To achieve this purpose, we have set the following goals:

- Analyze the current state of the use of innovative technologies in the public and private sectors;

- Compare the level of economy and public administration in the $90 \mathrm{~s}$ with the current times against the background of innovation processes;

- Get new statistics on innovations that determine the quality of management and business in Kazakhstan; 
- Contribute to the development of a scientific methodology that allows you to assess the effectiveness of the use of innovative resources.

\section{Methods}

The article uses methods of interdisciplinary research as the topic covers several areas and disciplines. Deduction and induction methods were used to identify factors that influence innovation policy and assess its state. And also actively used methods of analysis and synthesis that involves the study of socio-economic phenomena both in parts (analysis) and in General (synthesis). Due to the combination of analysis and synthesis, a systematic approach to complex research objects was provided.

In the course of writing this work, statistical materials were used of state bodies and holdings that regulate innovation activities in Kazakhstan. For example, we received data from the innovative project "Invest-2020" which was developed with the national holding Baiterek. As well as statistical indicators of Astana group holding for 2014-2019.

For an objective assessment of the development of innovation in Kazakhstan should be analyzed analytical data of the Global Innovation Index, which is developed by the International business school, Cornell University and the World Intellectual Property Organization. This study has existed since 2007 and represents the global scale of innovation development. In 2017, the scale of the study covered 143 countries, which are home to about $95 \%$ of the country's population and which produce about $99 \%$ of GDP (Nelson \& Winter, 2017). A total of 80 key indicators that make up the Global Innovation Index, which accurately reflect the development of innovation in any country in the world, regardless of the level of economic development. In this study, the basis of economic development is innovation potential. The Innovation Index is calculated by adding two groups of indicators:

1. Available resources and conditions for innovation;

2. The achieved practical results of the implementation of the innovation.

Consequently, the final Innovation Index is a cost-benefit ratio that allows to objectively assess the effectiveness of innovation development in a particular country (Abasov, 2020). According to this rating for 2018, Kazakhstan took 79th place in the list of 143 countries, which is five positions higher than in 2019 (Alimzhzhanov, 2011). Ten world leaders in the field of innovation in 2018 compared to 2019 have not suffered significant changes (Table 1 ).

At the first stage of the study, the influence of this Index on the countries' GDP values was investigated by constructing a statistical relationship between the GDP and the country's ranking position. The second stage was directed at comparing the state of innovative development of a particular nation with that of developed economies. The third research stage was aimed at developing recommendations on how to increase the country's innovative development level. 
Table 1 Global Innovation Index ranking 2018, 2019 (Alimzhzhanov, 2011)

\begin{tabular}{llllll}
\hline Rating & $\mathbf{2 0 1 8}$ & & $\mathbf{2 0 1 9}$ & Index \\
\cline { 2 - 3 } \cline { 5 - 6 } & Country & Index & & Country & 64.8 \\
\hline 1 & Switzerland & 67.9 & & Switzerland & 62.4 \\
3 & Sweden & 61.8 & & United Kingdom & 62.3 \\
4 & United Kingdom & 61.1 & & Sweden & 60.7 \\
5 & Netherlands & 61.1 & & Finland & 60.6 \\
5 & United States of America & 60.3 & & Netherland & 60.1 \\
7 & Finland & 59.5 & & United States of America & 59.2 \\
8 & Hong Kong & 59.4 & & Singapore & 57.5 \\
9 & Singapore & 59.4 & & Denmark & 56.9 \\
10 & Denmark & 58.3 & & Luxembourg & 56.8 \\
\hline
\end{tabular}

\section{Results and discussion}

In our view, the management of innovation processes is a set of consistent actions of all subjects of the innovation system, which are coordinated at all levels of management (planning, organization, motivation, control, regulation) and they all strive and move in the same direction, strive to achieve sustainable economic development through innovation at this stage.

In our understanding, the innovation process must be distinguished at the macro and micro levels. This does not mean separation and does not give reason to think that these are different things, it allows you to distinguish the management objects of a single whole innovation process.

At the macro level, the innovation process, first, refers to the stage from the choice of an innovative development path to a certain period, and second, the transformation and development of each individual component of the innovation economy. Driving the innovation process, the state should coordinate and identify the innovative potential of enterprises, scientific-technical potential, innovative infrastructure, and identify competitive and innovative position, to build innovation strategy and policy management, thereby taking over the functions of regulation and coordination. The key components in this case will be:

- National innovation system;

- State and innovative strategy for economic development;

- State methods and mechanisms for managing innovation processes.

The above mechanisms have long been mastered in Western countries in the late $90 \mathrm{~s}$. At the first stage of the study, the value of the Global Innovation Index for Kazakhstan was compared with its GDP (Table 2). Here should be mentioned that the country's position in the Global Innovation Index is in direct relationship with its GDP (Fig. 1).

The constructed regression relationship between the factors under study (Rating $=8 \mathrm{E}-07 *$ GDP5 $-0.0008 *$ GDP $4+0.286 *$ GDP $3-52.955 *$ GDP $2+4854.2 *$ GDP $\left.-176,140, R^{2}=0.8698\right)$ indicates that the innovation component is not decisive in the country's economy, which is fully consistent with other studies 
Table 2 Kazakhstan's GDP values and Global Innovation Index ranks for 2012-2020. Based on data retrieved from [https://www.globalinnovationindex.org/Home, https://gtmarket.ru/news/2013/07/ 01/6051, https://knoema.ru]

\begin{tabular}{llllllllll}
\hline Year & $\mathbf{2 0 1 2}$ & $\mathbf{2 0 1 3}$ & $\mathbf{2 0 1 4}$ & $\mathbf{2 0 1 5}$ & $\mathbf{2 0 1 6}$ & $\mathbf{2 0 1 7}$ & $\mathbf{2 0 1 8}$ & $\mathbf{2 0 1 9}$ & $\mathbf{2 0 2 0}$ \\
\hline $\begin{array}{l}\text { GDP, billion } \\
\text { dollars }\end{array}$ & 208 & 236.64 & 221.42 & 184.39 & 137.29 & 166.81 & 179.34 & 181.67 & 165.73 \\
Rank & 104 & 84 & 79 & 78 & 82 & 83 & 81 & 79 & 77 \\
\hline
\end{tabular}

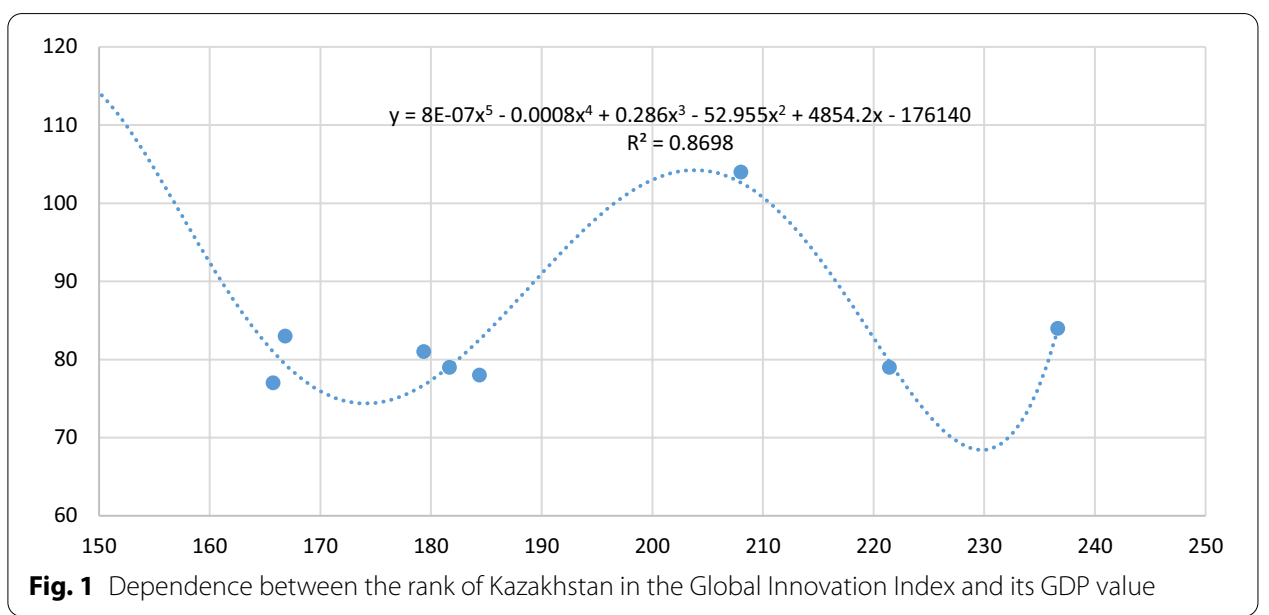

on the matter (Turganbayev \& Diener, 2018). Despite the fact that Kazakhstan does have the mechanism regulating innovation activity, the actual state of innovationrelated measures and efforts in the country suggests that it is far from being effective both at the level of the economy and at the level of individual industries, regions, and enterprises.

Low innovation activity indicators are a consequence of the shortcomings of the commercialization of the research and development sphere, as well as the weakness of the system of knowledge and technology transfer in the economy. The most critical factors provoking the decline in technological competitiveness are represented by the lack of financial and institutional systems for ensuring innovative and technological development, underdeveloped system for knowledge and technology transfer, and poor domestic demand for new technological developments (including that coming from the state itself).

At the second research stage, the position of Kazakhstan in the Global Innovation Index was compared with the ranks of developed countries. As can be noted, Kazakhstan is in the top fifty (Table 3).

Switzerland is still in the lead. It is followed by the United Kingdom, Sweden, Finland, the Netherlands, the United States, Singapore, Denmark, Luxembourg and Hong Kong. The ranking of the top 10 countries in the world has not changed much, except for entering the top 10 of Luxembourg, so Ireland lost its place in the top 10, but it is still included in the ranking of the top 25 countries. According to the world economic forum for 2018-2019, the rating of global competitiveness of Kazakhstan is at 42 positions, which indicates its increase by 8 points compared to last year. Stability at the macroeconomic 
Table 3 Ranking of countries in the world by the level of innovative opportunities and results

\begin{tabular}{lll}
\hline No & Countries & Period \\
\hline 1 & United Kingdom & $2018-2019$ \\
2 & Sweden & $2018-2019$ \\
3 & Finland & $2018-2019$ \\
4 & Netherlands & $2018-2019$ \\
5 & United States & $2018-2019$ \\
6 & Singapore & $2018-2019$ \\
7 & Denmark & $2018-2019$ \\
8 & Luxembourg & $2018-2019$ \\
9 & Hong Kong & $2018-2019$ \\
10 & Ireland & $2018-2019$ \\
42 & Kazakhstan & $2018-2019$ \\
\hline
\end{tabular}

level, the development of scientific and technological progress and explains the increase in this rating.

Foreign experience shows that today, there are three models of countries' scientific and innovative development:

1. States with a high innovation ratio that are focused on leadership in scientific research and large-scale targeted projects covering all research and production stages (United States, Great Britain, France). This is where an innovative type of society is being formed;

2. States seeking to expand innovation by creating a favorable scientific and technological environment (Germany, Sweden, Switzerland);

3. States focused on the stimulation of the development of an innovative infrastructure to ensure the acceptance of global scientific and technological achievements. Such countries tend to coordinate the activities of various branches of science and technology (Japan, South Korea).

Basically, in a broad sense, innovation is synonymous with the successful development of social, economic, educational, managerial, and other areas based on innovation. Scientific and scientific-technical development, the invention becomes innovation, being embodied in the goods, services as well as methods. Consequently, the innovation cycle is preceded by research, development or design work. Their results create the groundwork on the basis of which innovation begins.

It should be emphasized that by innovative development, it is understood the chain of realized innovations. It is more successful when it covers not one narrow area, but also includes areas that affect the overall result (management, marketing, staff training, finance, sales, and so on). According to Lundvall this is a complex question.

First and foremost, it is necessary to conduct an active innovation policy, which provides for the creation and development of appropriate institutional conditions and circumstances. The development of which, in turn, basically requires a detailed review of the national innovation system, and the identification of weak points and problems of its functioning to outline the main ways of improvement (Carañana et al., 2016). 
From this perspective, it can be said that the innovation process is an ever-changing combination of various types of creative work, united by a special organization-management and having a single targeted focus on obtaining innovations with a set of functions. The main factors of its dynamics can be considered first of all like elements of labor, its motivation, resource equipment; organization and management of competition; and environmental conditions. This is a set of objective factors, along with which a group of subjective factors acts strategy, policy, risk, etc.

The success of completing the full cycle of the innovation process and obtaining a specific result of innovation activity depends on the availability of innovative potential and effective management of it. To achieve the above arguments, you need the mechanisms that will be specified in Table 4 .

At this time, Kazakhstan has succeeded on the first (innovation strategy, innovation policy) buyer of significant success. And for the rest of the criteria need serious approaches. In developed countries, a positive result has been achieved, and innovation is a priority in socio-economic development, thanks to the competent and effective management of innovation processes.

In the State of the Nation Address of President of the Republic of Kazakhstan Nursultan Nazarbayev has noted that "...Sustainable growth will help us to ensure production diversification. While in the conditions of strong competition with liberal imports, the process of adapting production and entire industries to the market is underway, while our products, apart from raw materials, are not competitive on the world market, we are increasingly falling into a heavy raw structure of production, while the whole world is going in the opposite direction ..." (Mukhamedzhanov, 2011).

Actually, this statement corresponds to the experience of economic development of the leading countries of the world economy and determines the direction of innovative development of the economy of Kazakhstan.

At the third stage of the study, a number of suggestions on how to enhance the level of innovative development in the country were developed. They are as follows:

- Accumulation of financial resources for scientific research both at the expense of the budget and by creating special funds;

- Comprehensive assistance to the development of science, including applied science, and the formation of small-sized innovative entrepreneurship;

Table 4 Necessary mechanisms for effective management of innovation activities of public and private enterprises

\begin{tabular}{ll}
\hline No & Machinery \\
\hline 1 & Innovation strategy, innovation policy \\
2 & Scientific and technical base \\
3 & Innovative managers, intellectual potential \\
4 & Financial resources \\
5 & Well-established communication with the \\
6 & external and internal environment \\
\hline
\end{tabular}


- Facilitation of public orders for scientific research to spur the initial demand for innovations and their diffusion in the economy;

- Coordination of innovative activities to ensure innovations' compatibility;

- Stimulation of innovative activity by supporting competition and using economic methods of direct and indirect nature (financial subsidies, allowances, insurance, etc.);

- Staffing of innovative projects by creating appropriate training programs in state educational institutions to further increase the creative potential of the nation;

- Formation of scientific and innovative infrastructure, information systems, legal advisory services;

- Provision of institutional support to innovation processes through the creation of state organizations and subdivisions that carry out research and development and encourage innovations in the field of the public sector (defense, health care, education);

- Regional regulation of innovation processes through rational innovation potential management and use;

- Regulation of the international aspects of innovation processes by defining general economic and innovation strategies aimed at international scientific and technical cooperation.

Today, the mechanism of state regulation of innovative development is viewed as an indispensable element of the country's economic management system. This mechanism allows the state bodies to form the central innovation system of the country by setting specific goals, objectives, and innovative growth trajectories; define a system of political, economic, and legal methods; determine the ways of influence on the motives of people's activities; and create organizational forms and structures that provide opportunities and conditions for the development of the innovation sphere at the level of an enterprise, industry, region, and the whole country.

Summing up the above judgments about innovative development, in a condensed conceptual form, the strategy of innovation activity in Kazakhstan is the need for a production infrastructure capable of supplying goods to the world market that enjoy steady demand in the face of any competition. As is known, the structure of the economy of Kazakhstan has so far retained a raw material orientation. The main products of export are non-renewable mineral resources, which, as mentioned earlier, in different years make up $75-80 \%$ of total exports. Among them-in the sections of the commodity nomenclature-mineral products-up to $55 \%$, non-precious metals and products from them up to $32 \%$, products of chemical and related industries $6.0 \%$ (Kazakhstan-, 2030, 2015).

Next it is necessary to pay attention to the issues, which distinguishes innovations from inventions and modernization, and what they will give countries and societies. Modest mineral reserves and competing positions in the Global Innovation Index by the International Business School INSEAD, Cornell University and the World Intellectual Property Organization (WIPO). Each year, WIPO assesses the innovation activities of 126 countries on 80 parameters. The criteria include the political 
situation, education, infrastructure development, business, and the financing of the research sector as well (Analytical Review, 2020).

As it can be seen, Kazakhstan occupies the 74th position in this ranking. It should be noted, however, that Kazakhstan is in third place after India and Iran among the countries of South and Central Asia (Nekrasov, 2016). A country with a commodity and oil based economy, such as Kazakhstan, needs to develop high-tech production and technology, because mineral reserves are not unlimited, and with the development of renewable energy sources, demand for oil can fall. Saudi Arabia, for example, has decided to build the largest network of solar power plants on the planet with a capacity of 200 nuclear reactors. This innovative project aims to rid the state of oil dependence by 2030 .

It is known that innovation is the result of intellectual activity, imagination, creativity and human rationalization as well. Innovations are brought to the market in the form of products and goods with new useful properties (Carañana et al., 2016). Innovation improves the user's and consumer's experience. In this case, electric cars, Internet banking, 3D printing, or an e-government site are examples of innovation that solve problems faster, more efficiently, and more easily.

According to the most common classification, we divide all innovations into four types, which are shown in Table 5.

In the new conditions, the decisive factor is the speed of changes and adaptability to them. The most important factor of competition is not so much the volume, but the speed in making decisions and actions. Thus, an innovator can be any enterprising person, regardless of whether he has a scientific degree or significant professional experience. In this regard, Kazakhstan will have to form an integrated and integrated system of support and stimulation of innovation, as well as a corresponding innovation environment. It should be especially noted that many problems in the sphere of innovations lie in a different plane than the financial one. As international experience shows, a rather important aspect for the intensification of innovation activity is the formation of a receptive environment adequate to the innovation culture.

Table 5 Classification of innovation activity

\begin{tabular}{lll}
\hline No The name of the type & Type description \\
\hline $1 \quad$ Product innovation & $\begin{array}{l}\text { Product innovation is the introduction of a product or service with new or sig- } \\
\text { nificantly improved properties or method of use. In addition to that, improved } \\
\text { product specifications, software, or user-friendliness can be the essence of } \\
\text { product innovation }\end{array}$ \\
2 Process innovation & $\begin{array}{l}\text { Process innovation is a significant improvement in the way we produce or } \\
\text { deliver a product. Laser machine and 3D-modeling technology in construction } \\
\text { are examples of process innovations }\end{array}$ \\
4 Marketing innovations & $\begin{array}{l}\text { Organizational innovations consist in improving business processes, introduc- } \\
\text { ing new HR practices or methods of external communication of companies as } \\
\text { well innovations } \\
\text { Marketing innovations are actually involved in improving product design, } \\
\text { market promotion, and pricing, expanding the audience and increasing sales } \\
\text { profits }\end{array}$ \\
\hline
\end{tabular}




\section{Conclusions}

The formation of a new type of innovation system in Kazakhstan is just beginning. However, already these days, it is possible to distinguish the key problems in the formation and implementation of state innovation policy in the country. They cover such aspects as:

- Poor business environment manifested in underdeveloped conditions for fair competition, as well as for obtaining state support;

- Significant barriers to the spread of new technologies in the economy due to the lack of state policy on innovation and ineffective industry regulation;

- Insufficient efforts made by regional and local authorities to improve conditions for innovation;

- Irregular interaction of business and the state in the formation and implementation of innovation policy, which fails to ensure a balance of interests of various innovation-active enterprises;

- Low efficiency of state instruments supporting innovation because of the limited flexibility, underdeveloped mechanisms for distributing risks between the state and business, soft focus on the stimulation of ties between various innovation processes participants and on the formation and development of scientific, industrial, and technological partnerships.

At the same time, the progressive practice of foreign countries to increase the level of innovative development is grounded on organizational, economic, and financial instruments.

Nevertheless, despite the problematic nature of quickly creating an effective national innovation economic model and the difficulty of integrating science, business and education, today, in the republic, new innovative structures are being formed and prerequisites are being created to ensure the balanced development of all elements of the innovation system in the framework of the next decade and until 2050.

Certain important steps in this direction have already been made. A new international university has been created in Astana, which will be focused on the best international quality standards. This will be the first university of the world level in the post-Soviet space. For its functioning, the best specialists from abroad will be invited and the best training practices will be developed.

To train personnel for the new economy, intellectual schools of the First President are being created in all regions of the country. They should become the place of distribution of the most advanced educational experience in the world.

The above steps will allow in practice to solve the systemic problem of the formation of an intellectual nation.

Future research on the matter will be focused on the development of approaches to the formation of an effective mechanism for implementing the strategy of innovative development of the national economy.

Summing up, it is worth noting that the planned transition indicated in the President's Address to the active introduction of innovations and the formation of an innovationtype economy becomes virtually no alternative to the future in modern conditions. 
Without overestimating its values and roles, innovative activity should become one of the priority directions of the state policy of Kazakhstan in the upcoming perspective.

\section{Abbreviations}

IP: Innovation process; WIPO: World Intellectual Property Organization.

\section{Acknowledgements}

Not applicable.

\section{Authors' contributions}

MS, KYu and BI contributed equally to the experimentation. MS and KYu wrote and first draft of the article. KYu and BI equally designed and conducted the experiment. MS and KYu studied scientific literature about the topic. BI edited the final version of the manuscript. All authors read and approved the final manuscript.

\section{Funding}

This research did not receive any specific grant from funding agencies in the public, commercial, or not-for-profit sectors

\section{Availability of data and materials}

All data will be available from the corresponding upon reasonable request.

\section{Declarations}

\section{Competing interests}

The authors declare that they have no competing interests.

\section{Author details}

${ }^{1}$ Department of Sociology and Social Work, Al-Farabi Kazakh National University, Almaty, Kazakhstan. ${ }^{2}$ Department of Special Education, Abay Kazakh National Pedagogical University, Almaty, Kazakhstan. ${ }^{3}$ Department of Economics and Business, Abay Kazakh National Pedagogical University, Almaty, Kazakhstan.

Received: 10 November 2020 Accepted: 15 September 2021

Published online: 26 September 2021

\section{References}

Abasov, Z. (2020). Innovations in education and synergetics. Alma-Mater, 4, 3-7.

Alimzhzhanov, B. (2011). From parallels -To a real innovation model. History of Sovereign Kazakhstan: 20 years of Independence. Nauka Publishing.

Analytical Review. (2020). Innovation activity in the Republic of Kazakhstan: State and problems of development. Analytical review.

Bassellier, G., Reich, B. H., \& Benbasat, I. (2001). Information technology competence of business managers: A definition and research model. Journal of Management Information Systems, 17(4), 159-182.

Begentayev, M. M. (2018). Innovative potential of Kazakhstan: Theory, methodology, development mechanism. Toraigyrov Pavlodar State University.

Bhatt, G. D., \& Grover, V. (2005). Types of information technology capabilities and their role in competitive advantage: An empirical study. Journal of Management Information Systems, 22(2), 253-277.

Bukhalova, N. A. (2018). Innovation as a means of economic development: A review of scientific theories. Economic Theory, 3(34), 91-102.

Carañana, C. D., Peris-Ortiz, M., \& Rueda-Armengot, C. (2016). What are the competences in information system required by managers? Curriculum development for management and public administration degrees. Technology, Innovation and Education, 2(1), 1-9.

Carlsson, B., \& Stankiewicz, R. (1991). On the nature, function and composition of technological systems. Journal of Evolutionary Economics, 1(2), 93-118.

Chesbro, G. (2017). Open innovations. Pokolenie Publishing.

Efremova, N. F. (2018). Formation and evaluation of competencies in education: Monograph. ARKOL.

Freeman, C. (2015). Technology, policy, and economic performance: Lessons from Japan. Pinter Publisher Ltd.

Gareev, T. F. (2017). Evolution of models of innovation process. Bulletin of Moscow University, 2, 91-114.

Gogoleva, B. (2017). Innovation management: Textbook. Publishing and Trading Corporation "Dashkov and $C^{\circ . "}$

Grant, R. M. (1996). Toward a knowledge-based theory of the firm. Strategic Management Journal, 17(S2), 109-122.

Kazakhstan-2030. (2015). Prosperity, safety and improvement of the welfare of all Kazakhstanis. Message of the President of the country to the people of Kazakhstan. Kazakhstanskaya Pravda.

Kazhymurat, K. (2017). Selected scientific works. Kazakhstan Lady of Institutions.

Kline, S. J., \& Rosenberg, N. (2015). An overview of innovation. The positive sum strategy: Harnessing technology for economic growth. National Academy Press.

Kudryavtseva, E. I. (2019). Competence and management: Competence in management, competence of managers, management of competencies. North-West Institute of Management, Russian Academy of Public Administration and National Economy. 
Lundvall, B.-A. (2016). National systems of innovation: Towards a theory of innovation and interactive learning. Pinter Publisher Ltd.

Mukhamedzhanov, DSh. (2011). The structure of the economy of Kazakhstan in the plans of forced industrialization. Efficiency state forced programs of industrial innovative development in the eyes of the population (pp. 58-64). Kazakhstan Institute Strategic Research under the President of the Republic of Kazakhstan.

Naumenko, E. O. (2016). On the issue of models of innovation process management on the enterprise in modern conditions. Polythematic Network Electronic Scientific Journal of the Kuban State Agrarian University (scientific Journal of Kuban), 4(20), 22-38.

Nekrasov, V. (2016). Kazakhstan in the era of innovation. Industry of Kazakhstan, 1(76), 58-71.

Nelson, R. R., \& Winter, S. G. (2017). Innovation as a new development method. Harvard University Press.

Rothwell, R. (2015). Towards the fifth-generation innovation process. International Marketing Review, 11(1), 7-21. https:// doi.org/10.1108/02651339410057491

Turganbayev, Y., \& Diener, A. C. (2018). Kazakhstan's evolving regional economic policy: Assessing strategies of postsocialist development. Eurasian Geography and Economics, 59(5-6), 657-684. https://doi.org/10.1080/15387216. 2019.1586559

\section{Publisher's Note}

Springer Nature remains neutral with regard to jurisdictional claims in published maps and institutional affiliations.

\section{Submit your manuscript to a SpringerOpen ${ }^{\circ}$} journal and benefit from:

- Convenient online submission

- Rigorous peer review

- Open access: articles freely available online

- High visibility within the field

Retaining the copyright to your article

Submit your next manuscript at $\boldsymbol{\Delta}$ springeropen.com 